\title{
Study of an Enzyme Activity in Extracts of Ginkgo biloba Leaves
}

\author{
Seongsoon Park \\ Department of Chemisty, Center for NanoBio Applied Technology, and Institute of Basic Sciences, \\ Sungshin Women's University, Seoul 136-742, Korea. E-mail: spark@sungshinackr \\ Received July 17, 2006
}

Key Words : Ginkgo extracts, Peroxidase, Biocatalyst

Biocatalyst is a strong tool for preparation of enantiopure compounds through kinetic resolution or direct synthesis.' However, enzymes do not always satisfy the needs of researchers for this purpose because they often do not have enough activity or selectivity toward unnatural substrates. To solve the problems, it is important to find new enzymes from nature, although researchers have tried to change enzyme activity or selectivity by mutagenesis such as random mutagenesis and rational design. ${ }^{2}$ Researchers have isolated a variety of enzymes from various sources such as bacteria, fungi, mammals, and plants. Diabetic enzymes such as lipases and proteases from bacteria and mammals are well characterized and utilized successfully in academic and industrial areas. ${ }^{3}$ The enzymes involved in mechanisms for protecting plants from insect or fungal attack are also useful in organic synthesis. ${ }^{4}$ Such enzymes generally catalyze reactions to produce toxic chemicals in the last step of secondary metabolism to kill predators. As an example, hydroxynitrilases from cyanogenic plants catalyze the bjodegradation of cyanogenic glycosides to release hydrogen cyanide. The reverse reaction is interesting in organic synthesis because hydroxynitrilases catalyze formation of enantiopure cyanohydrins from aldehydes or ketones and hydrogen cyanide.

Searching enzymes involved in the secondary metabolism of plants may provide useful biocatalysts in organic synthesis because the enzymes have a key role for synthesis of many biologically active compounds. Ginkgo biloba leaves have high anti-insect activity and biological activity. ${ }^{6}$ Thus, they might contain an interesting enzyme involved in the secondary metabolism and the enzyme can be useful for organic synthesis. We have chosen Ginkgo biloba leaves for finding a new enzyme because Ginkgo biloba leaves potentially contain enzymes involved in the secondary metabolism and also the study of the enzymatic activity of extracts from Ginkgo leaves has not been focused ${ }^{7}$ while the chemicals in them have been well characterized. ${ }^{8}$ Herein, we represent an enzyme activity in Ginkgo biloba leaves.

Most enzymes are classified into six groups, such as oxidoreductase, transferases, hydrolases, lyases, isomerases, and ligases.' Activities for oxidoreductase, hydrolase, and lyase were chosen for screening enzyme activities in Ginkgo biloba leaves because these enzymes are important in organic synthesis. ${ }^{10}$ We assayed the activities of peroxidase for oxidoreductase, $\beta$-amylase, nitrilase, and esterase for hydrolase, and hydroxynitrilase for lyase. Ginkgo biloba
Table 1. Enz̧̧me actrvitıes in Ginkgo leaves

\begin{tabular}{lc}
\hline tested enzyme activity & activity (units/mg) \\
\hline Peroxidase activity & $6.4 \times 10^{-2}$ \\
Hydroxynitrilase activity & n.d \\
Nitrilase activity & n.d \\
Esterase activity (hydrolysis) & n.d \\
Esterase activity (transesterification) & n.d \\
$\beta$-Amylase activity & n.d \\
\hline
\end{tabular}

"Assay condition: see the experimental section. "One unit of peroxidase is defined as the amount of enzyme required to catalyze the production of $1 \mathrm{mg}$ of purpurogallin from pyrogallol under the assay conditions described. "n.d: nol detected.

leaves were ground by a homogenizer and washed with ethyl acetate to remove organic components. Ginkgo powders were extracted with the reaction buffers for activity screening. Under the assay condition tested, Ginkgo extracts showed only the peroxidase activity (Table I). In the assay condition, peroxidases oxidize pyrogallol to purpurogallin using hydrogenperoxide (eq. 1). The absorbance change can be monitored at $420 \mathrm{~nm}$. The reaction coordinate showed clear difference between the reaction by Ginkgo extracts and the blank reaction (Figure 1 ).

2 pyrogallol $+3 \mathrm{H}_{2} \mathrm{O}_{2} \rightarrow$ purpurogallin $+5 \mathrm{H}_{2} \mathrm{O}+\mathrm{CO}_{2}$

The absorbance change may occur by some non-catalytic proteins or metal jons. To see if non-catalytic proteins or metal ions perform the oxidation, BSA (bovine serum albumin) as well as iron(II) ion was tested under the same assay condition (Table 2, entries 3-4). The initial rates for

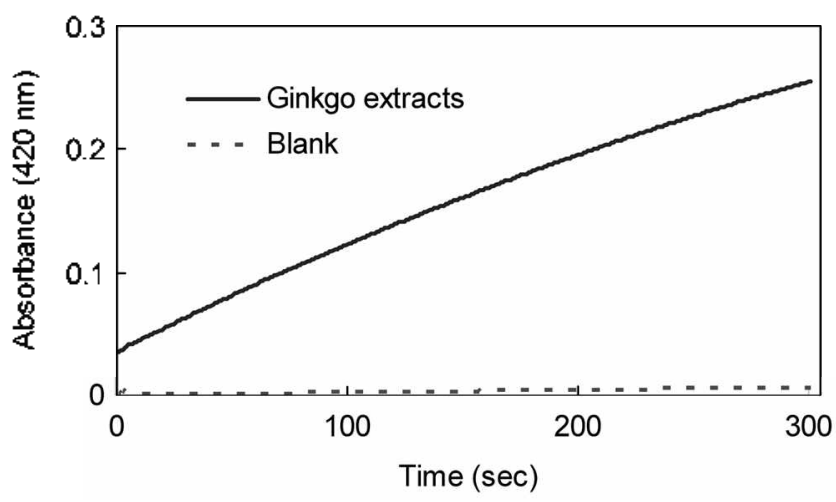

Figure 1. The time course of the oxidation of pyrogallol by Ginkgo extracts. Ginkgo extracts catalyze the oxidation of pyrogallol 100 fold faster than the blank reaction. 
Table 2. Peroxidase activity of Ginkgo extracts and that with additives $^{\text {it }}$

\begin{tabular}{lll}
\hline entry & \multicolumn{1}{c}{ additives } & \multicolumn{1}{c}{ activity $^{b}$ (units $/ \mathrm{mL}$ ) } \\
\hline 1 & Ginkgo extracts $(36 / \mathrm{g} / \mathrm{mL})$ & $2.3 \times 10^{-3} \pm 0.13 \times 10^{-3 .}$ \\
2 & Blank & $3.0 \times 10^{-5}$ \\
3 & BSA $(1 \mathrm{mg} / \mathrm{mL})$ & $4.6 \times 10^{-5}$ \\
4 & $1 \mathrm{mM} \mathrm{FeSO}$ & $1.1 \times 10^{-5} \pm 0.54 \times 10^{-5}$ \\
5 & Ginkgo extracts with $\mathrm{NaN}_{3}(10 \mathrm{mM})$ & $1.4 \times 10^{-4} \pm 0.44 \times 10^{-4}$ \\
6 & Ginkgo extracts with EDTA $(10 \mathrm{mM})$ & $2.2 \times 10^{-3} \pm 0.21 \times 10^{-3}$ \\
7 & Horseradish peroxidase $(36 \mu \mathrm{g} / \mathrm{mL})$ & $4.3 \times 10^{-1}$ \\
\hline
\end{tabular}

"The reaction condition: see the experimental section. For blank and other reactions, the same volume of buffer or the solution of additives, respectively, were added to the reaction mixture. For the reactions with sodium azide and EDTA, the same volume of the solutions ( $10 \mathrm{mM}$ ) was added to the Ginkgo extracts and incubated at rit. for $\mathrm{l}$ hr before assayed. "The activity was calculated by the following equation: (units $/ \mathrm{mL}$ ) $=$ $\left[\Delta \mathrm{A}_{420 \mathrm{~mm}} /\right.$ time $(\mathrm{sec}) \times$ reaction volume $\left.(\mathrm{mL})\right] /[$ molar extinction coefficient $(12) \times$ volume of enzyme solution $(0.050 \mathrm{~mL})]$. "See the definition in the table 1. "Etrots are standard deviations for at least three measurements; enities withoul etrors are single measuremenis.

both cases were similar to that for the blank reaction. In addition, sodium azide was added in the reaction mixture of Ginkgo extracts if the reaction can be inhibited by a known inhibitor of peroxidases. Sodium azide reduced the initial reaction rate by a factor of 10 (Table 2 , entry 6 ). For comparison with a commercial peroxidase, we have measured the activity of horseradish peroxidase with same protein concentration. The peroxidase activity in Ginkgo extracts was about 200 times lower than that of horseradish peroxidase (compare entry 1 with entry 7 in Table 2). Ginkgo extracts may contain many inactive proteins for peroxidase activity. Although the peroxidase activity in Ginkgo extracts is lower than a commercial purified peroxidase, these results show that Ginkgo extracts presumably contain a peroxidase.

It is important to find new enzyme to expand the scope of biocatalysis. Ginkgo extracts contain a lot of biologically active compounds. Several metabolisms and enzymes would be involved in the synthesis of these compounds. Thus, it is worth to searching new enzyme activities from Ginkgo extracts. Ginkgo extracts clearly showed peroxidase activity. The peroxidase can be useful in organic synthesis because oxidation is a key reaction to generate a chiral building block such as chiral epoxides. " At this stage, it is rather difficult to define the characteristics of peroxidase in Ginkgo extracts. For continuous research, we are planning to compare the distinct characteristics of peroxidase in Ginkgo extracts with peroxidases from other plants and apply the Ginkgo extracts to synthesis of chiral compounds.

\section{Experimental Section}

All chemicals, buffers, and horseradish peroxidase were purchased from Sigma-Aldrich Korea (Yongin, Korea). Protein assay kit (Bio-Rad Laboratories, Hercules, CA) was used for determining the amount of proteins in extracts of Ginkgo biloba leaves as the manufacturer's direction. The leaves were obtained from the Ginkgo biloba trees in the garden of the Sungshin Women's University. The leaves were ground by a homogenizer (Nihonseiki Kaisha Ltd., Tokyo, Japan). UV/Vis (Varian technologies, Seoul, Korea) was used for determining the amount of proteins and for enzyme assay.

Treatment of Ginkgo biloba leaves with organic solvents. Ginkgo biloba leaves were frozen and ground by a homogenizer at $1500 \mathrm{rpm}$ for $30 \mathrm{~min}$ with dry ice filled around it. The powders of Ginkgo Biloba leaves $(60 \mathrm{~g})$ were added into ethyl acetate $(60 \mathrm{~mL})$. The suspension was stirred and kept at $4{ }^{\circ} \mathrm{C}$ for 6 hours and filtered. This procedure was repeated until the green color disappeared (about 7 times). The pale green powders were air dried at room temperature. The dried powders were kept in a freezer $\left(-25^{\circ} \mathrm{C}\right)$ until use.

Preparation of extracts of Ginkgo biloba leaves. The Ginkgo powders $(200 \mathrm{mg})$ were added to $1 \mathrm{~mL}$ of the buffer solutions (potassium phosphate, $100 \mathrm{mM}, \mathrm{pH} 6.0 ;$ MOPS, 5 $\mathrm{mM}, \mathrm{pH} 7.2$; sodium citrate, $50 \mathrm{mM}, \mathrm{pH} 5.5$ ) and kept at 4 ${ }^{\circ} \mathrm{C}$ for 24 hours. After centrifuge $\left(30 \mathrm{~min}, 13000 \mathrm{rpm}, 4{ }^{\circ} \mathrm{C}\right.$ ), the supernatant was used for the further experiments. The amount of protein in the Ginkgo extracts was determined as $36 \mu \mathrm{g} / \mathrm{mL}$.

Peroxidase activity. ${ }^{12}$ The assay solution was prepared by mixing potassium phosphate buffer $(160 \mu \mathrm{L}, 100 \mathrm{mM}, \mathrm{pH}$ 6.0 ), hydrogen peroxide solution ( $80 \mu \mathrm{L}, 0.5 \mathrm{wt} \%$ ), pyrogallol solution $(160 \mu \mathrm{L}, 5 \mathrm{w} / \mathrm{v} \%)$, and Milli-Q water $(1,050 \mu \mathrm{L})$. The extracts of Ginkgo Biloba leaves $(50 \mu \mathrm{L})$ were added to the above assay solution. The total volume was $1.5 \mathrm{~mL}$. The reaction was monitored at $420 \mathrm{~nm}$ for $5 \mathrm{~min}$.

Hydroxynitrilase activity. For the reaction, the powders of Ginkgo Biloba leaves ( $300 \mathrm{mg}$ ) were equilibrated by adding of sodium citrate buffer $(120 \mu \mathrm{L}, 20 \mathrm{mM}, \mathrm{pH} 5.5)$. Sodium cyanide $(110 \mathrm{mg})$ was dissolved in milli-Q water $(1.5 \mathrm{~mL})$ and adjusted $\mathrm{pH}$ to 5.5 by addition of acetic acid. Isopropyl ether $(2.5 \mathrm{~mL})$ was added to the solution. The organic layer containing hydrogen cyanide was separated and added to the vial containing the powders of Ginkgo Biloba leaves. To start the reactions, benzaldehyde $(100 \mu \mathrm{L})$ was added. And the reaction was monitored by TLC (ethyl acetate : hexane $=1: 5$ ).

Nitrilase activity. To a suspension of the ground Ginkgo leaves $(100 \mathrm{mg})$ in a potassium phosphate buffer solution $(5$ $\mathrm{mL}, \mathrm{pH} 7.0,100 \mathrm{mM}$ ) was added 1,4-dicyanobenzene $(300$ $\mathrm{mg}$ ). The mixture was shaken at $30^{\circ} \mathrm{C}$. The reaction was monitored by TLC (ethyl acetate : hexane $=1: 1$ ).

Acylation of 1-phenylethanol. To a solution of vinyl acetate $(92 \mu \mathrm{L})$ and 1-phenylethanol $(120 \mu \mathrm{L})$ in diethyl ether $(2 \mathrm{~mL}$ ) was added the ground Ginkgo leaves $(30 \mathrm{mg})$. The reaction mixture was stirred at room temperature and the reaction was monitored by TLC (ethyl acetate : hexane $=$ $1: 5)$.

Hydrolysis of $p$-nitrophenyl acetate. An assay solution was prepared by mixing $p$-nitrophenyl acetate solution ( 20 $\mu \mathrm{L}, 200 \mathrm{mM}$ in acetonitrile), acetonitrile $(870 \mu \mathrm{L})$, and MOPS buffer $(11,110 \mu \mathrm{L}, 5 \mathrm{mM}, \mathrm{pH} 7.2)$. To the assay solution $(3 \mathrm{~mL})$ was added the Ginkgo Biloba extracts $(150$ $\mu \mathrm{L}$, in MOPS, $\mathrm{pH} 7.2,5 \mathrm{mM})$. The reaction was monitored 
by UV/Vis spectra at $404 \mathrm{~nm}$.

$\beta$-Amylase activity. Color reagent solution was prepared by mixing sodium potassium tartrate tetrahydrate $(12.0 \mathrm{~g})$, $\mathrm{NaOH}$ solution (8 mL, $2 \mathrm{M}), 3.5$-dinitrosalicylic acid solution $\left(20 \mathrm{~mL}, 96 \mathrm{mM}\right.$ ), and adding $\mathrm{ddH}_{2} \mathrm{O}$ up to $40 \mathrm{~mL}$. To a starch solution $(1.0 \mathrm{w} / \mathrm{v} \%, 1 \mathrm{~mL})$ was added the ground powders of the ground Ginkgo leaves $(100 \mathrm{mg})$. The suspension was stirred at $20^{\circ} \mathrm{C}$ for $20 \mathrm{~min}$. The color reagent solution $(1 \mathrm{~mL})$ was added to the suspension and heated at $100^{\circ} \mathrm{C}$ for $15 \mathrm{~min}$ and cooled to room temperature. After the solution was diluted with $\mathrm{ddH}_{2} \mathrm{O}(9 \mathrm{~mL})$, the absorbance was measured at $540 \mathrm{~nm}$.

Acknowledgement. This work was supported by the Sungshin Women's University research grant, 2006-1-11022/1. The author thanks Hyojin Park, Jungwon Suh, Heehyun Kim, and Soyoung Shin for initial experiments. And also the author thanks the referees for useful comments.

\section{References}

1. Review: (a) Davis, B. G.; Boyer, V. Nat. Prod. Rep. 2001, $/ 8,618-$ 640. (b) Kim, M.-J.; Ahn, Y.; Park, J. Bull. Kor. Chem. Soc. 2005. 26. 515-522.

2. Reviews: (a) Robertson, D. E.; Steer, B. A. Curr. Opin, Chem.
Biol. 2004, 8, 141-149. (b) Dalby, P. A. Curr: Opin, Strict, Biol. 2003, J3, 500-505. (c) Cherry, J. R.; Fidantsef, A. L. Curr. Opin. Biotechnol. 2003, 14, 438-443. (d) Chen, R. Trents Biotechnot 2001, 19, 13-14. (e) Bornscheuer, U. T.; Pohl, M. Curr. Opin. Chem. Biol. 2001, 5, 137-143. (f) Petrounia, I. P; Amold, F. H. Curr. Opin. Biotechnol. 2000, 11, 325-330.

3. Bornscheuer, U. T.; Kazlauskas, R. J. Hydrolases in Organic Synthesis; Wiley-VCH: Weinheim, 1999.

4. Review: Osbourn. A. E. Plant Cell 1996, 8, 1821-1831.

5. Vetter, J. Toxicon 2000, 38, II-36.

6. Gertz, H.-J.; Kiefer, M. Com. Pharm, Des. 2004, 10, 261-264.

7. However, several enzymes in Ginkgo biloba were cloned very recently: Shen, G.; Pang. Y.; Wu. W.; Deng, Z.; Zhao, L.; Cao, Y.; Sun, X.; Tang, K. Biosci. Rep. 2006, 26, 19-29; Okazawa, A.; Tango. L.; Itoh. Y.; Fukusaki. E.; Kobayashi. A. Z. Naturforsch. C 2006, 61, 111-117; Wu, W:: Pang, Y.: Shen, G. A.: Lu, J.: Lin, J.: Wang, J.: Sun, X.: Tang, K. J. Biochem. Mol. Biol. 2006, 39, 158-166; Gong, Y. F.; Liao, Z. H.; Guo, B. H.; Sun, X. F.; Tang. K. X. Planta Med. 2006, 72, 329-335; Kim, S. M.; Kuzuyama. T.; Chang. Y. J.; Kim, S. U. Plant Cell Rep. 2006, in press.

8. Review: van Beek, T. A. J. Chromalogr. A 2002, 967, 21-55.

9. Faber, K. Biotransformations in Organic Chemistry; 4th Ed.; Springer: Berlin, 2000; p 22.

10. Faber, K. Pure Appl. Chem, 1997, 69, 1613-1632.

11. Aziridines and Epoxides in Organic Synthesis; Yudin, A. K., Ed.; Wiley-VCH: Weinheim, 2006.

12. Chance, B.; Naehly, A. C. Methods in Enzymology 1955, 2, 773775 . 